Bol. Acad. peru. leng. 67. 2020 (11-49)

\title{
ANCESTROS Y EROTISMO EN OCTAVIO PAZ: ANÁLISIS RETÓRICO DE DOS POEMAS DE SEMILLAS PARA UN HIMNO
}

\section{ANCESTORS AND EROTICISM IN OCTAVIO PAZ: RHETO- RICAL ANALYSIS OF TWO POEMS SEMILLAS PARA UN HIMNO (SEEDS FOR A HYMN)}

\author{
Johnny Zevallos \\ Universidad Nacional Mayor de San Marcos \\ pchujzev@upc.edu.pe \\ https://orcid.org/0000-0002-4923-3097
}

\section{Resumen:}

La obra poética de Octavio Paz fusiona la tradición mesoamericana, anterior a la conquista europea, con la cultura asiática —especialmente india, china y japonesa-. Se trata, por ello, de un aporte valioso para el encuentro de aquellas voces que, a pesar de las distancias continentales, reflejan cierta semejanza en las construcciones mítica y erótica del discurso poético. El autor mexicano supo fundar un universo poético que recogía ambas tradiciones, aunque sin fusionarlas, lo que constituye una aproximación a dos culturas aparentemente disímiles para hallar las fuentes fundacionales de los mundos náhuatl y chino. Para analizar esta propuesta, nos enfocamos, por un lado, en la teoría retórica y discursiva de Arduini con respecto al uso retórico de las figuras literarias tradicionales, 
y, por otro lado, en la propuesta de Lakoff y Johnson para las metáforas de uso cotidiano.

Palabras clave: poesía, Mesoamérica, náhuatl, cultura asiática, metáforas.

\section{Abstract:}

Octavio Paz's poetic work fuses the Mesoamerican tradition prior to the European Conquest, with the Asian culture -especially Indian, Chinese and Japanese. Therefore, it's a valuable contribution to the convergence of those voices that, despite continental distances, reflect a certain similarity in the mythical and erotic constructions of poetic discourse. The Mexican author knew how to find a poetic universe that captures both cultures' traditions, although without merging them, which constitutes an approach to two apparently dissimilar cultures in order to find the foundational sources of the Nahuatl and Chinese worlds. To analyze this proposal we focus, on one hand, on Arduini's rhetorical and discoursive theory, regarding the rhetorical use of traditional literary figures, and, on the other hand, Lakoff and Johnson's proposal for everyday metaphors.

Key words: poetry, Mesoamerica, Nahuatl, Asian culture, metaphors.

Fecha de recepción:

Fecha de aceptación:
$04 / 01 / 2020$

$25 / 03 / 2020$

\section{Introducción}

La obra poética de Octavio Paz constituye uno de los pilares fundamentales de la poesía vanguardista y surrealista de Hispanoamérica, ya que incorpora elementos como «la temporalidad, el movimiento del mundo, la historia y, nuevamente, el lenguaje» (Sucre, 1977: 51). Esta construcción de imágenes ha constituido un aporte muy significativo, pues determina el valor que supone el aporte de Paz para la poesía en español. Por ello, ante la vasta 
producción literaria del autor mexicano, hemos decidido centrarnos en uno de sus poemarios: Semillas para un bimno (1943-1954), dado que el título incide en la preocupación de algunos de sus contemporáneos, es decir, hallar el origen (la semilla) de la cultura amerindia.

Nos avocamos a analizar dos poemas: «Fábula» y «Primavera y muchacha», los cuales comparamos con otros dos que se relacionan con estos y que aparecen en el mismo poemario: «Cerro de la estrella»y «[La muchacha de movimientos de río]». La elección de estos textos corresponde a nuestro interés de preguntarnos a qué obedece el término semilla y de qué manera este permite explicarnos si existe una relación con un origen mítico mesoamericano o si hay puntos en común con otras culturas.

La hipótesis que tratamos de demostrar en este ensayo es la existencia de una esencia común en el universo poético de Semillas para un himno, dado que el fuego y la luz representan el valor central en la propuesta lírica del autor. Consideramos que, siendo Paz un lector apasionado de las culturas amerindia y asiática, estas pudieron influenciar en su producción.

En ese sentido, la metodología que empleamos para sustentar nuestra hipótesis se basa en el estudio de la retórica empleado por Stefano Arduini en su libro Prolegómenos a una teoría general de las figuras (2000), pues se trata de un trabajo que contribuye a desentrañar el uso de la retórica y la teoría del lenguaje para decodificar los problemas lingüísticos que plantea la poesía. Además, utilizamos el ya clásico estudio que proponen George Lakoff y Mark Johnson en su Metáforas de la vida cotidiana (1980), en el cual plantean las diferentes metáforas que posibilitan un acercamiento más riguroso al enfoque del análisis poético y a comprender el uso de las metáforas como interpretación de las ideas literarias expuestas en los poemas de Paz.

De esta manera, dividimos el presente artículo en tres acápites, a fin de analizar con detenimiento la propuesta poética que aparece en los textos seleccionados. En el primero, que hemos titulado «Campo retórico en Semillas para un bimno", exponemos los antecedentes críticos en torno a este poemario y otros acercamientos a la poesía de Octavio Paz, a fin de descubrir con qué lecturas críticas (de las diferentes posturas existentes 
en torno al libro en mención) podemos estar de acuerdo y cuáles podemos contraargumentar. Además, se establecerá un marco teórico que nos permite adentrarnos en los postulados que planteamos en los dos acápites restantes acerca del análisis retórico de los poemas.

El segundo acápite tiene como finalidad analizar el campo figurativo de los poemas «Fábula» y «Primavera y muchacha» a partir de una fragmentación de cada texto y la interpretación de cada parte desde una perspectiva interdisciplinaria, es decir, que incluya otras lecturas. Así, se espera proponer nuevos aportes acerca de la poética de Paz mediante los trabajos de Miguel León-Portilla en cuanto a la cosmovisión náhuatl y los estudios del propio Paz sobre el mundo amatorio y erótico taoísta e hindú. Asimismo, a través del ya mencionado trabajo de Arduini, establecemos un estudio de las principales figuras poéticas que aparecen en los textos seleccionados, a fin de ofrecer un análisis más profundo de la visión del mundo propuesta por el autor mexicano.

Finalmente, brindamos una aproximación al estudio de las metáforas en el universo lírico de Paz en Semillas para un himno, centrándonos especialmente en las metáforas orientacionales y en las metáforas ontológicas. Para dicho fin, es de utilidad el libro de George Lakoff y Mark Johnson, pues ofrece un nuevo aporte al análisis de estas figuras. El propósito de esta sección es demostrar, desde la perspectiva poética, que existe un origen común en cuanto a los universos mentales y los elementos ancestrales entre las sociedades mesoamericanas y las asiáticas, ya que los ritos religiosos de los ancestros o filosófico-eróticos tienen una línea común en el fuego y el agua.

\section{El campo retórico en Semillas para un himno}

En su clásico libro Prolegómenos a una teoría general de las figuras, Stefano Arduini sostiene que el campo figurativo consiste en «la vasta área de los conocimientos y de las experiencias comunicativas adquiridas por el individuo, por la sociedad y las culturas. Es el depósito de las funciones y de los medios comunicativos formales» (2000: 47). Vale decir, representa los antecedentes sobre el libro en estudio y cómo ha sido su recepción 
en el marco cultural de la sociedad a la que pertenece. Además, debe incluirse el marco teórico que posibilita la estructura mental de los poemas seleccionados, cuál es el contexto social y cultural, y cómo se relaciona con los problemas de interpretación que pueden plantearse. De esta manera, Arduini proporciona un marco más completo acerca de los factores previos que todo texto poético plantea al lector.

Dentro de las lecturas que pretendemos comentar, nos centramos en aquellas que han abarcado especialmente Semillas para un himno o temas afines en la poesía de Paz. En ese sentido, dividimos la presente sección del estudio en dos partes: un breve estado de la cuestión sobre el poemario y el marco teórico que nos posibilita el análisis.

\subsection{Breve estado de la cuestión sobre Semillas para un himno}

La introducción que elaborara Enrico Mario Santí para Libertad bajo palabra permite adentrar al lector en el magnífico universo poético de Paz aclarando algunas dudas acerca de esta monumental colección de poemarios. De esta forma, explica qué periodos abarca el libro y cómo algunas etapas influyeron notablemente en la construcción de los textos allí congregados. Santí señala que es un «libro total que, a la vez, se autolimita en el tiempo; deliberada y sucesiva revisión de un ciclo en la vida y obra de un poeta» (Paz, 2014: 62). Así, el crítico cubano sostiene que Semillas para un bimno corresponde a las estancias de Paz en Europa y Oriente y, luego de un largo periodo de ausencia, regresa a México para reencontrarse con las huellas culturales que lo habían marcado inicialmente. Acerca de este poemario, indica lo siguiente:

Se trata de una lírica breve, espontánea y grácil, deliberadamente opuesta a la extensa y reflexiva de La estación violenta. «La imagen es la parte central», ha dicho de ellos.

[...]

En los poemas breves de Semillas para un bimno confluyen, por eso, el haiku japonés, la poesía náhuatl, la poesía popular española y la lírica moderna, sobre todo la de inspiración cubista. Pero será el interés por la literatura japonesa el que cultiva en algunos de los textos más penetrantes. (2014: 47) 
Creemos que es evidente la influencia de la poética náhuatl en la construcción de los poemas, así como la presencia de la estructura japonesa; sin embargo, consideramos que la presencia de la filosofía taoísta es igualmente importante, como lo intentamos demostrar en los acápites siguientes. Se trata, por ello, de un libro que abarca una multitud de influencias y que absorbe varias mentalidades y las transforma de manera extraordinaria. La comparación con La estación violenta (1948-1957) es esencial, por cuanto en esta los poemas son sumamente extensos y recuerdan, sobre todo, a la estética india a través de imágenes y concepciones propias de la tradición védica, y la historia y religión hinduista. El aporte de Santí es sustancial, además, para comprender la propuesta de Paz, dado que ha publicado otros estudios a la obra del autor mexicano.

Otro autor que ha dedicado varias líneas al estudio de Semillas para un bimno es el norteamericano Antonhy Stanton, quien destaca que «representa la cima central de una poesía de comunión» (1992: 12). Para Stanton, las reflexiones poéticas de Paz aluden a un origen milenario a través del título mismo del poemario, que alude al germen o semilla de la civilización azteca.

El título postula un tiempo de germinación (semillas) que desembocará en un futuro canto religioso, un himno cuyo principal referente interno en la recopilación es «Himno entre ruinas», posterior en el orden poético del libro, pero escrito con anterioridad. Retrospectivamente, el folleto es una bisagra de transición y una prefiguración embrionaria de la madurez poética. (1992: 12)

Se trata, en efecto, de un encuentro religioso con los ancestros a través de un lenguaje que recoja lo más excelso del pasado mesoamericano, a fin de recuperar la esencia poética del pueblo náhuatl. Por ello, al analizar el poema «Fábula», Stanton se detiene en el poder de las imágenes al que recurre Paz para recrear el origen mítico del pueblo azteca, por lo que se centra en la escena metafórica del lenguaje y los espejos rotos a la que remiten los últimos versos del texto. El crítico opta por una interpretación directa de los versos antes que atender el uso de las imágenes como 
construcción de un universo meramente poético. De esta manera, el crítico afirma que frente a la ruptura del lenguaje (a partir de los espejos rotos que menciona el poema) se asume que «a una cosmovisión fracturada corresponde un lenguaje fragmentario. En lugar de ser signo arbitrario, la palabra sigue siendo un espejo mágico que refleja lo real» (1992: 14). Creemos que esta interpretación no atiende a su relación con el mito, ya que supone una lectura teórica del lenguaje y no desde una valoración de la cosmovisión náhuatl.

Guillermo Sucre sostiene que en Semillas para un bimno se pretende hallar el origen de la identidad mexicana, dado que se articula la palabra con el acto poético mismo. Es la búsqueda de una identidad a través de la poesía hacia el campo del origen mítico y de lo erótico, factores con los que estamos de acuerdo.

[...] en poemas como los de Semillas para un himno lo real y el lenguaje son dos maneras distintas pero paralelas de transcurrir el mundo; es decir, uno y otro son encarnaciones recíprocas y equivalentes. La duda es, pues, sustituida por la confianza ante el lenguaje. Pero de una u otra forma el poema es movimiento extático. (1971: 54)

La construcción del lenguaje poético en Paz — sugiere Guillermo Sucre- está íntimamente vinculada con la palabra y las figuras que en ella se erigen. El tiempo y la palabra se complementan en la imagen porque para el autor mexicano, sostiene el crítico, la segunda encierra todo lo que la poesía debe significar. Esta percepción es quizá la que más se acerca a lo que busca Paz en sus poemas, dado que ella «busca de la unidad poética y también de la del mundo» (1971: 55). Este acercamiento al mundo poético del autor de Libertad bajo palabra tiene como escenario plantear dos momentos: «uno de estos momentos parece sugerir el fracaso de la palabra; el otro, su plenitud» (1971: 54).

Por su parte, el crítico Antonio Puro Morales acierta al señalar que en nuestro libro en estudio aparecen algunos aspectos fundamentales como «la oposición entre fuego y agua: el fuego implícito en la idea sémica de relámpago y el agua implícita en la de lágrima» (1982: 149). 
No obstante, yerra en entender la poesía de Paz al definir que «en el poema "Primavera y muchacha", donde la mujer es identificada con la flor, elemento primaveral por excelencia de la naturaleza», pues introduce imágenes propias de una poesía bizantina. Nuestro interés al analizar este poema es interpretar este texto a partir de una filosofía taoísta en la que incursionó el autor durante este periodo. Por ello, sorprende que el crítico haya pasado por alto estas indicaciones y no se detuviera en incorporar la influencia de las culturas que el poeta mexicano experimentó en sus lecturas y viajes a Oriente. El crítico finaliza su estudio con una idea interesante acerca de los que considera elementos centrales del poemario y su relación con la mujer, pues esta «necesita ser agua, tiene que ser agua para el poeta, porque este necesita beber en ella sus raíces, observar su propio y más íntimo ser y, al mismo tiempo, comunicarse con los otros en el mar de la existencia» (1982: 154).

Por último, Fernández Cozman, al acercarse a un estudio sobre $L a$ estación violenta, señala, para el caso de «Piedra de sol», que «es un poema intercultural donde se percibe el diálogo (no exento de conflicto) entre la cultura occidental y las civilizaciones prehispánicas» (2015: 6). En ese sentido, las huellas prehispánicas que encuentra el crítico son evidentes y permiten conocer con profundidad el aporte que presenta el interés de Paz por poetizar los orígenes mesoamericanos del universo lírico mexicano. $\mathrm{Al}$ respecto, Fernández acierta al afirmar:

Octavio Paz, en este caso, abraza la fe en un proyecto político a través de la metáfora del «árbol de anchas hojas de turquesa» como testimonio de la fe en la transformación de la sociedad en un mundo donde reinen la justicia y la libertad. (2015: 16)

Esta posición convierte a Paz en un autor que supo aprovechar las imágenes del mundo náhuatl y de las culturas orientales para proponer un mundo poético que absorbiera con maestría las influencias de sociedades aparentemente lejanas de su origen hispanoamericano. La estructura de sus poemas, evidentemente bajo la presencia del vanguardismo y el surrealismo, admite otros influjos que suponen un elemento indudablemente cercano con los proyectos poéticos más logrado de la lírica universal. 


\subsection{El marco teórico para analizar Semillas para un bimno}

A fin de construir un corpus verdaderamente amplio de la poesía de Octavio Paz y, sobre todo, de su poemario Semillas para un himno, consideramos apropiado utilizar, por un lado, la filosofía náhuatl. Miguel León-Portilla indica que el universo azteca estaba regido por una serie de elementos centrales (fuego, agua, aire y tierra), lo cual predomina en la mentalidad de las colectividades prehispánicas. Esta asociación mental es utilizada magistralmente por el autor de La estación violenta, ya que ha logrado construir proyectos poéticos que toman en cuenta la presencia de una literatura prehispánica ya existente antes de la llegada de los europeos. Cabe indicar que tanto Paz como León-Portilla pertenecían a un periodo que pretendía reivindicar a las culturas amerindias. Por ello, para este último, «sucede con los nahuas lo mismo que con los griegos, donde fueron precisamente los poetas líricos los que empezaron a tomar conciencia de los grandes problemas que rodean la comprensión del mundo y del hombre» (1993: 5). Es más, el mismo autor agrega:

hay base documental para ello, es que llevados de hecho los nahuas por su preocupación de «forjar rostros ajenos» y de «humanizar el querer de la gente», llegaron espontáneamente —al igual que otras de las grandes culturas clásicas - a la creación directa y no diferenciada aún de lo que el pensamiento occidental moderno designa hoy como un sistema educativo, ético, jurídico, social. (1993: 219)

Se trata, pues, de un aporte que profundiza y rescata el universo mental mexica y que la poesía de Paz sabrá recrear en los poemas de Semillas para un himno y luego en La estación violenta. No obstante, la otra fuente que el autor sabrá utilizar está constituida por el mundo oriental y su relación con el erotismo y la filosofía taoístas. Como se sabe, el poeta mexicano fue un prolífico ensayista y conocedor profundísimo de las prácticas culturales de Oriente, la misma que se propuso investigar. En su colección de ensayos Conjunciones y disyunciones, observamos algunas muestras del valor estético que empleó Paz para interpretar y decodificar el mundo asiático. Esta estética es concebida por el autor como adherentes a la naturaleza de los confucionistas, quienes señalaban la manifestación del cuerpo y el no-cuerpo. 
Por ello, existen diferentes cuerpos como el «cuerpo biológico individual, cuerpo social familiar, cuerpo político imperial, cuerpo del cosmos» (Paz, 1991: 139). Así, esta expresión corporal tendrá un valor significativo para la construcción del orden poético chino y su expresión amatoria y erótica: el erotismo también es una expresión poética.

Las utilizaciones de los elementos de la antigüedad también están presentes en Oriente y Paz las emplea para plasmar ideas que, si bien son distintas en el mundo prehispánico, tienen una función similar. Así, los chinos veían en los elementos naturales un acercamiento a la estructura cíclica del orden y la jerarquía en la armonía existencial de los individuos.

En el confucianismo la sublimación se expresa como neutralización de los signos por una progresiva parálisis. Una inmovilidad que, para cumplirse más efectivamente, da la ilusión del movimiento: la naturaleza se vuelve cultura y ésta, a su vez, se enmascara en falsa naturaleza que, de nuevo, se convierte en cultura y así sucesivamente. (1991: 140)

El orden de las cosas en el universo confucionista y taoísta se centra en transmitir la naturaleza a través de la participación corporal y espiritual al mismo tiempo, ya que no ve diferencias entre ellas. De esta manera, la participación de los amantes logrará que se profundice la naturaleza y puedan llegar a un estado de felicidad y pureza a través del amor. Esta constante transformación de la naturaleza en cultura y viceversa puede entenderse como parte-complemento cíclico del yin y el yang, propio de las sociedades chinas y que también está presente en el mundo amerindio a través de la dualidad arriba-abajo. No es de extrañar que esta complementariedad llegó incluso con los propios europeos, ya que la presencia hispana en América estuvo contaminada por la mahometana, la cual a su vez aprehendió su arte y cultura de los hindúes. Por esta razón, la difusión de sociedades aparentemente lejanas no es tan arbitraria ni diferente como se cree.

\section{El campo figurativo en dos poemas de Semillas para un himno}

La retórica ha introducido algunos elementos que son esenciales para comprender la naturaleza de un poema, ya que ofrece un análisis riguroso 
que permite desentrañar la relación entre figura y lenguaje. Ya que cada palabra posee las dimensiones significante y significado, provoca que se pretenda decodificar los niveles de comprensión dentro de un poema a fin de definir cada signo textual. En el caso del poemario Semillas para un bimno (1954), es posible encontrar cómo algunos textos contienen imágenes que conducen a un campo de figuras dependientes de lenguajes expresivos y connotativos.

Estos lenguajes van a constituir una aproximación al contexto denotativo de los vocablos que integran cada poema. Nuestro interés en esta sección es analizar las diferentes imágenes que integran el campo figurativo de Semillas. De esta manera, nos adentramos en el universo poético de Paz a través de los poemas «Fábula», «Muchacha y primavera», "Cerro de la estrella» y «[Una mujer de movimientos de río]», pues contienen elementos que se relacionan con las fases náhuatl y china en la poesía de Paz, además de incidir en aspectos que indagan en relaciones culturales que las emparientan. Es importante señalar, por ello, que estas producciones representan un valor nuevo en la búsqueda de un nuevo lenguaje a través del enunciado breve.

\subsection{Análisis retórico del poema «Fábula»}

En el poema «Fábula» es posible advertir algunos elementos propios de la advocación al universo náhuatl y la voz de personajes propios de los rituales ancestrales prehispánicos. La preocupación del autor es la de trasmitir voces y figuras que remitan a la presencia de un universo mítico en la sociedad náhuatl.

\section{Fábula}

Edades de fuego y de aire

Mocedades de agua

Del verde al amarillo

Del amarillo al rojo

Del sueño a la vigilia 
Del deseo al acto

Sólo había un paso que tú dabas sin esfuerzo

Los insectos eran joyas animadas

El calor reposaba al borde del estanque

La lluvia era un sauce de pelo suelto

En la palma de tu mano crecía un árbol

Aquel árbol cantaba reía y profetizaba

Sus vaticinios cubrían de alas el espacio

Había milagros sencillos llamados pájaros

Todo era de todos

Todos eran todo

Sólo había una palabra inmensa y sin revés

Palabra como un sol

Un día se rompió en fragmentos diminutos

Son las palabras del lenguaje que hablamos

Fragmentos que nunca se unirán

Espejos rotos donde el mundo se mira destrozado. (2014: 190)

\subsubsection{Fragmentación y campo retórico del poema}

Es posible dividir el texto en tres fragmentos que remiten al mundo originario mesoamericano que Paz desea otorgar al texto. Así, el primer fragmento (versos 1-6), al que hemos titulado «La voz de los ancestros», hace alusión al mundo onírico de las visiones originarias, pues predomina un espacio de elementos naturales y colores, propios de un mundo antiguo. De esta manera, en el primer verso se puede leer Edades de fuego y de aire / Mocedades de agua como ideas que remiten a las voces náhuatl de la creación. Si se compara con los poemas del México antiguo, se puede comprobar una influencia notable. Así, en la antología que recoge Miguel León-Portilla, es posible advertir la confluencia de mitos que constituyen el origen del universo mexica. Por ejemplo, en el poema «Los soles o edades que han existido", se observa que el texto representa las edades de transformación del mundo por medio de la presencia de varios mundos que atraviesan fases o universos cósmicos.

El poema náhuatl, en sus primeros versos, es presentado por un locutor que describe un espacio natural donde, a su vez, se describe la 
voz de un dios supremo originario a través de códigos propios del ritual mágico.

Como lo sabían los viejos,

en el año 1-Conejo

se cimentó la tierra y el cielo.

Y así lo sabían,

que cuando se cimentó la tierra y el cielo,

habían existido ya cuatro clases de hombres,

cuatro clases de vidas.

Sabían igualmente que cada una de ellas

habían existido en un Sol (una edad). (León-Portilla, 1978: 7)

Los vocablos tierra y sol pueden hacer referencia a los colores rojo y amarillo, respectivamente, como se enuncia en el poema «Fábula», de Octavio Paz. Además, se menciona vidas como fases o edades y el término viejos podría remitir a ancestros u origen, hecho que queda sumamente claro en el poema en estudio. En ese sentido, el autor se preocupa por construir un texto que evidencie una relación estrecha con un germen o semilla de la mitología náhuatl. Al definir la semilla en su colección de ensayos Corriente alterna, sostiene que «es la metáfora original: cae en el suelo, en una hendidura del terreno, y se nutre de la sustancia de la tierra [...]. La hendidura en el tiempo anuncia el comienzo del reinado del hombre» (1967: 26-27).

A continuación, decidimos establecer una segunda fragmentación del poema que contiene el sueño dentro de un mundo paradisíaco descrito a través de imágenes que evocan a los dioses de la comunidad. De esta manera, entre los versos 7 y 16 puede leerse lo siguiente:

Sólo había un paso que tú dabas sin esfuerzo

Los insectos eran joyas animadas

El calor reposaba al borde del estanque

La lluvia era un sauce de pelo suelto

En la palma de tu mano crecía un árbol

Aquel árbol cantaba reía y profetizaba 
Sus vaticinios cubrían de alas el espacio Había milagros sencillos llamados pájaros Todo era de todos

Todos eran todo

El locutor se dirige por primera vez en el texto a un alocutario — a modo de desdoblamiento-y llama al interior de los individuos que componen la comunidad originaria del universo náhuatl. La presencia de insectos, calor, lluvia, árbol y pájaros representa un estado animista propio del mundo mitológico, por lo que el poeta la muestra al hombre como parte de ese universo al que se dirige. Cabe entender, por ello, que no puede escapar de ese espacio maravilloso y depende más bien de este. Se trata, pues de un viaje a un mundo onírico en el que el locutor le revela esa existencia a través de un escenario cósmico: el paraíso natural.

Continuando con el poema náhuatl titulado «Los soles o edades que han existido», es posible encontrar imágenes similares en las que el locutor muestra escenarios naturales que se relacionan con el texto de Paz.

Se cimentó luego el tercer Sol.

Su signo era 4-Lluvia.

Se decía Sol de Lluvia (de fuego).

Sucedió que durante él llovió fuego,

los que en él vivían se quemaron.

Y durante él llovió también arena.

Y decían que en él

llovieron las piedrezuelas que vemos,

que hirvió la piedra tezontle

y que entonces se enrojecieron los peñascos.

Su signo era 4-Viento, se cimentó luego en cuarto Sol.

Se decía Sol de Viento.

Durante él todo fue llevado por el viento.

Todos se volvieron monos. 
https://doi.org/10.46744/bapl.202001.001

Por los montes se esparcieron, se fueron a vivir los hombres-monos. (León-Portilla, 1978: 8)

En este fragmento, puede observarse la representación de imágenes que aluden a situaciones de construcción originaria del universo náhuatl como la lluvia, el viento, el sol, la piedra y el mono. Sin duda, esta relación de elementos insertados en el texto evoca a fases o círculos en los que el individuo ingresa y observa los cambios a modo de signos o figuras míticas. Así, al describirse el número cuatro como eje a partir del cual discurren otros escenarios, el locutor menciona el fuego como elemento creador y ordenador del universo. De este se desprenden otras figuras que se estrechan con el poema de Paz como la relación entre joyas y piedrezuelas, árbol y monos o, en otras líneas, con vínculos más claros como lluvia o viento. El viento remite al cielo, al aire, a los pájaros como seres que se relacionan con la divinidad. Ya que el fuego o el calor es el ordenador del orden mítico, el locutor ubica a su alrededor las imágenes que describe y busca legitimar su presencia a partir del tránsito de un rito de paso o viaje onírico. La creación del mundo desde la lluvia y el sol transmite el imaginario que construyen los habitantes nahuas.

En cuanto a la última fragmentación, los versos 17 al 22 constituyen el tránsito final del orden mitológico descrito en el poema, pues el individuo atraviesa un mundo mágico de ritos e historias mágicas, en el que prevalece la oralidad (palabra). Por ello, hemos creído conveniente titular al fragmento «La palabra y el mundo mágico náhuatl», ya que nos permite centrar nuestro análisis desde la propia simbología en que se construye el universo mítico mesoamericano. Al respecto, en los versos seleccionados puede leerse lo siguiente:

Sólo había una palabra inmensa y sin revés

Palabra como un sol

Un día se rompió en fragmentos diminutos

Son las palabras del lenguaje que hablamos

Fragmentos que nunca se unirán

Espejos rotos donde el mundo se mira destrozado. 
El término palabra hace referencia evidente a la presencia del hombre como sitio o escenario final del orden mítico. En ese sentido, Miguel León-Portilla señala con claridad que «el hombre concebido como colaborador de los dioses, particularmente el sol, Huitzilopochtli» (1993: 45) constituye la pieza central en dicho orden. El locutor recurre a imágenes de la divinidad para explicar el origen del lenguaje que, a su vez, indica el origen del caos, por lo que culpa a la palabra de la desarmonía en que viven los individuos. La palabra es el hombre mismo, es su espejo, su vínculo con la divinidad y la construcción de todo el orden. Si existe un orden determinado por el individuo, es porque este lo ha nominado: la palabra da vida a las cosas. En el universo mesoamericano, las voces de los dioses y los hombres son determinantes para ordenar el universo; es decir, la comunicación permite que los individuos puedan equilibrar lo que les rodea. Así, en el poema «El nacimiento de Huitzilopochtli, el Sol, en el pensamiento mexica», se puede observar algunas referencias al lenguaje como factor de creación, orden y nominación de los hechos a los que recurren los personajes.

Mucho honraban los mexicas a Huitzilopochtli, sabían ellos que su origen, su principio

fue de esta manera<smiles>[CH]1[CH]C=C1</smiles>

Al ver los cuatrocientos Surianos

que su madre estaba encinta, muchos se enojaron, dijeron:

—“¿Quién le ha hecho esto?

¿quién la dejó encinta?

Nos afrenta, nos deshonra".

Y su hermana Coyolxauhqui les dijo:

— "Hermanos, ella nos ha deshonrado, hemos de matar a nuestra madre". (León-Portilla, 1978: 13-14) 
Se trata de voces que el locutor muestra a partir del desorden del mundo cósmico mesoamericano, cuyo eje es la venganza. La desestructuración de la armonía nace en el universo mítico a través de la palabra, por lo que Paz recurre a la imagen de los espejos rotos en cuanto a figuras que rivalizan con otros dioses y ven la desaparición del otro como fin de sus tormentos. La palabra entonces contiene todos los elementos que nos dirigen a pensar que el mundo onírico puede conducir no necesariamente al orden cósmico, sino al fin de este: la desestructuración del universo. Dado que el hombre es el fin de la creación divina, puede ser entendido también como el responsable de su fin.

\subsection{Análisis de «Primavera y muchacha»}

Una idea similar es posible encontrar en el poema «Primavera y muchacha» que se incluye en Semilla para un himno. La relación amorosa de los amantes aparece marcada por la presencia de un alocutario femenino a quien el locutor dirige su voz a medida que va involucrando su presencia a lo largo del poema. Los versos presentan imágenes que incorporan el agua como elemento que remite al fluir del amor y el erotismo.

\section{Primavera y muchacha}

En su tallo de calor se balancea

La estación indecisa

$$
\text { Abajo }
$$

Un gran deseo de viaje remueve

Las entrañas heladas del lago

Cacerías de reflejos allá arriba

La ribera ofrece guantes de musgo a tu blancura

La luz bebe luz en tu boca

Tu cuerpo se abre como una mirada

Como una flor al sol de una mirada

Te abres

Belleza sin apoyo 
https://doi.org/10.46744/bapl.202001.001

Basta un parpadeo

Todo se precipita en un ojo sin fondo

Basta un parpadeo

Todo reaparece en el mismo ojo

Brilla el mundo

Tú resplandeces al filo del agua y de la luz

Eres la hermosa máscara del día. (Paz, 2014: 197)

El locutor muestra el erotismo en su fase más amplia al comparar la intimidad de la mujer con la flor, ya que ve en la relación íntima sexual entre hombre y mujer una influencia evidente de la filosofía erótica china. A continuación, presentamos un análisis detallado a partir de una fragmentación del poema y la relación con el campo retórico que encontramos a lo largo del texto.

\subsubsection{Estudio retórico y fragmentación del poema}

El primer fragmento que hallamos en el texto abarca los versos 1 al 6, al cual titulamos «La búsqueda del deseo», ya que nos adentra en el escenario en que se consumará el acto amoroso entre los amantes. Al respecto, el autor no duda en representar la naturaleza como escenario al establecer un «tronco de calor» $\mathrm{y}$ «cacerías de reflejo» para dirigirse a «cazar» a la amada. Esta imagen incorpora dos polos que se oponen o complementan; es decir, la dualidad abajo/arriba se corresponde con la dualidad mujer/hombre o femenino/masculino. Una mujer aparentemente indecisa necesita de la voluntad de un hombre que vaya hacia ella, que se adentre en su interior y procure tomarla para sí. Paz reconoce, en ese aspecto, la influencia de la filosofía erótica china al proponer:

Desde su origen, la civilización china concibió al cosmos como un orden compuesto por el ritmo dual unión, separación, unión de dos poderes o fuerzas: el cielo y la tierra, lo masculino y lo femenino, lo activo y lo pasivo, yang y yin. (Paz, 1991: 127)

Esta dualidad enuncia la construcción de una que sea esencial para que se complemente el amor, por lo que nuestra segunda fragmentación, 
que ocupa los versos 7 al 18, incluye a un alocutario, que es interpelado por un locutor. Para un mejor análisis del fragmento, decidimos titularlo «Encuentro coital entre el agua y el fuego». En el caso del alocutario, este es presentado como un sujeto femenino blanco que asume un rol líquido frente a la luminosidad del varón, ya que el locutor afirma que «la luz bebe luz en tu boca». Esta interpretación puede desprenderse a través del acercamiento de Paz a la cultura erótica china:

El ideograma de la unión sexual en el I Ching es Chi-chi: arriba el triagrama $\mathrm{K}$ 'an (agua, nube, mujer) y abajo el triagrama Li (fuego, luz, hombre) [...]. Si el universo es cíclico y fluido, la inmortalidad debe ser vida que fluye y que recurre. (1991: 133)

El encuentro coital puede advertirse en la presencia del hombre en la intimidad de la mujer mediante el beso o el sexo oral al penetrar la luz (hombre) en el líquido (beber, mujer) que ingresa en la boca de esta. Esta construcción de imágenes sensuales, sensoriales, remiten a la mujer como ser que se abre para que el hombre pueda penetrarla mediante la enunciación de «Tu cuerpo se abre como una mirada / Como una flor al sol de una mirada / Te abres». La penetración ejerce, sin duda, la dominación del hombre y Paz lo entiende en $E l$ laberinto de la soledad (1950) como la condición de interponer un valor sustancial basado en el poder androcéntrico, es decir, en lo que dispone un sujeto masculino para sí y los demás a partir de lo que establece una comunidad que reúne estas características. A pesar de que concentran el poder, los hombres deben someterse a la categoría de «no rajarse», pues sobre ellos pesa el ejercicio de la dominación y el de no perderlo.

Finalmente, el poema hace hincapié en la capacidad del erotismo de reunir ambos sexos en la consumación del acto erótico al interpelar al alocutario y manifestarle que «resplandeces al filo del agua y de la luz / Eres la hermosa máscara del día». La condición de máscara supone el ocultar la belleza de la mujer poseída tras el coito, lo cual puede entenderse como la transfiguración o mutación hacia un nuevo cuerpo que aparece como una nueva fase: el mañana como un nuevo despertar. 


\subsection{Análisis de las figuras en «Fábula» $\mathrm{y}$ «Primavera y muchacha»}

El empleo de figuras dentro del lenguaje poético de Paz es asumido a partir del análisis retórico visto en el acápite anterior. De esta manera, nos adentramos en el uso de figuras como metonimia, enumeración, elipsis, antítesis y repetición. El universo poético del autor mexicano permite entrañar las imágenes a través de cosmovisiones y mundos diferentes entre sí que aportan a su construcción. La retórica nos permite, entonces, decodificar con mayores argumentos la visión del mundo que desea expresar el autor en cada poema. En ese sentido, la elección de cada texto resulta más clara a partir del empleo de esta herramienta de interpretación, pues nos adentramos en la decodificación de los significantes y significados que utiliza el poeta, a fin de desentrañar cada poema.

Por tanto, elegimos las figuras a analizar, pero solo en aquellos casos en que es útil su empleo, con el propósito de no originar alguna repetición en cada texto. El hecho de restringir el campo figurativo para demostrar la hipótesis planteada en la introducción. La interpretación resulta, por ello, más amplia, por cuanto ayuda a consolidar la finalidad de nuestro estudio.

\subsubsection{La metonimia en «Fábula» $\mathrm{y}$ «Primavera y muchacha»}

En el poema «Fábula», podemos encontrar empleo de la metonimia en el verso 22, ya que el autor utiliza un elemento que sustituye el todo por la parte, a fin de dar a entender un lenguaje que recupere la oralidad, propia de las sociedades mesoamericanas. Así, el verso muestra:

Son las palabras del lenguaje que hablamos

Fragmentos que nunca se unirán

Espejos rotos donde el mundo se mira destrozado

El empleo del vocablo mundo en reemplazo de individuos contribuye a entender el propósito del locutor de enfatizar la necesidad de integrar a los hombres con su lenguaje, su realidad y su dificultad. Para la comunidad mexica, el hecho de querer incorporarse a sus leyendas o historias míticas, a 
partir de la lengua como factor original de la posibilidad de crear historias y poesía, constituirá un interés sobrenatural. El locutor, entonces, cree ver en los espejos rotos la dificultad que le supondrá la desestructuración de su universo al incluir a todos los seres humanos como generadores de comunicación e incomunicación al mismo tiempo, pues impide que se miren a sí mismos como parte de una colectividad.

En el poema «Primavera y muchacha», es posible advertir la reiteración del uso de mundo para referirse ya no solo a la totalidad de individuos, sino al espacio en que se comete el acto sexual descrito en el texto. Así, el fragmento muestra lo siguiente:

Todo reaparece en el mismo ojo

Brilla el mundo

Tú resplandeces al filo del agua y de la luz

La palabra mundo se entiende como la totalidad del cuerpo femenino que brilla, luce diferente, tras el acto amatorio que comete la pareja. Se trata de un nuevo cuerpo que se estremece, agita, convulsiona, pues ha alcanzado el clímax de su totalidad sexual. El locutor aspira, por tanto, a representar los brillos con que esta nueva mujer aparece: la primavera es, para ella, la consumación del placer erótico a través de una naturaleza que la absorbe y muestra como tal.

Asimismo, en este mismo poema se advierte cómo un órgano puede ser representado por su función, hecho que el locutor desea mostrar como símbolo máximo de la belleza en una mujer durante el acto erótico.

\section{Belleza sin apoyo \\ Basta un parpadeo \\ Todo se precipita en un ojo sin fondo}

En el verso 14, el ojo (mirada) representa la atracción total, en una mirada puesta en un solo punto: el clímax que ha conducido a los amantes a admirarse mutuamente. Sin embargo, también puede leerse como la vagina, mientras que todo se relacionaría con el semen, que es vertido 
(precipitado) en el interior del órgano reproductor femenino. Paz extrae esta semejanza con la consumación del acto sexual de la filosofía erótica china, en la que se apela a referentes corporales o de movimiento a fin de retratar el momento más intenso del coito. El locutor nos adentra en este escenario para mostrarnos el placer que conduce a los amantes a la posesión definitiva de la mujer.

Asimismo, en el poema «Primavera y muchacha», podemos advertir la utilización de fonemas que intercambian significados, en los que el locutor espera incrementar la necesidad de remarcar el sentido erótico del texto.

Cacerías de reflejos allá arriba

La ribera ofrece guantes de musgo a tu blancura

La luz bebe luz en tu boca

El hecho de intercambiar el término guantes por rocas incide en la fortaleza con que el locutor desea presentarse ante el alocutario a fin de atraerlo hacia sí. Esta invocación a la atracción no tiene otro fin más que el deseo de poseer a la mujer blanca a partir de una característica fenotípica (aria, blanca), lo que constituiría, sin duda, el interés del locutor por remarcar su deseo mediante el beso. La necesidad de mostrarse aguerrido, imponente, se vincula con el tacto (mano, guante) como símbolo de unión sexual entre ambos.

Este mismo texto recurre a imágenes de sensualidad que la filosofía erótica china recurre para explorar todas las posibilidades de enamoramiento y consumación del acto carnal entre hombre y mujer.

Tu cuerpo se abre como una mirada

Como una flor al sol de una mirada

Te abres

La asociación de la flor con la vagina es apelada por la mayoría de sociedades orientales, especialmente en la India y específicamente con la flor de loto, ya que en los textos sagrados tántricos esta flor abre sus pétalos para ser penetrada por el sol y goza con el tacto de manos fuertes 
(Wolf, 2013: 284). Al abrirse al hombre, la flor permite que este logre conquistarla y penetrarla con sus rayos de luz. El sol representaría la fortaleza del hombre, como sinónimo de virilidad y presencia dominante en la escena expuesta en el poema.

Finalmente, el locutor enfatiza la influencia del universo erótico chino al incorporar (como ya se vio en la sección anterior) la relación entre el agua (mujer) y la luz (hombre) en la consumación de la posesión carnal.

Tú resplandeces al filo del agua y de la luz

Eres la hermosa máscara del día

La asociación de estos vocablos ayuda a construir esta filosofía erótica, a contemplar el amor-pasión como un fluir de elementos naturales que representan «lo no-determinado, lo que cambia sin cambiar, lo que nunca se detiene y esta inmóvil» (Paz, 1991: 134). Esta aparente inmovilidad de los cuerpos tiende a favorecer la belleza de la mujer, pues ya no la compara solo con el agua, sino que le otorga el poder dominante al calificarla con adjetivos como resplandor o máscara del día. De esta forma, el locutor nos presenta un ser que ha pasado del estado subalterno al hegemónico tras la culminación de la fase erótica.

\title{
2.3.2. Elipsis en «Fábula»y en «Primavera y muchacha»
}

A partir de la eliminación de la conjunción y, el poeta tiene la libertad de no crear una dependencia o relación entre los elementos, sino de distribuirlos de acuerdo con una adecuación formal. En el poema «Fábula», el locutor nos muestra una serie de elementos distribuidos según una secuencia de tonalidades o acciones.

\author{
Del verde al amarillo $[y]$ \\ Del amarillo al rojo \\ Del sueño a la vigilia $[y]$ \\ Del deseo al acto (vv. 3-6)
}


https://doi.org/10.46744/bapl.202001.001

Todo era de todos $[\mathrm{y}]$

Todos eran todo (vv. 15-16)

El empleo de los colores corresponde a un significado mítico en el que se asocia los ciclos o edades del mundo náhuatl. Miguel León-Portilla ha identificado la lucha entre las fuerzas cósmicas representadas por los colores de Quetzalcóatl en los antiguos códices aztecas (1992: 111-112). Se trata de fases solares en las cuales los dioses disponen «en un combate que se desarrolla en cada uno de los Soles, desde los cuatro rumbos del mundo y por medio de una oposición de elementos» (p. 112).

Además, en los versos siguientes, el sueño corresponde al viaje con los ancestros, el universo náhuatl que corresponde al mundo de los dioses. La supresión de la «y» permite enfatizar el juego mágico de los elementos mitológicos, pues estos aparecen como un brote maravilloso de las acciones descritas por el locutor. Por ello, al pasar de un estado a otro es posible atravesar de manera casi lúgubre de un estado mágico a otro más real, en el que la acción constituye el último tramo al que recurren los dioses en los mitos náhuatl.

Finalmente, en los versos 5 y 6 , podemos hallar no solo una metonimia que recurre a la totalidad (naturaleza), sino a la contemplación de la humanidad como poseedora de ella. En ese sentido, la eliminación de la conjunción copulativa tiende a incrementar lo ritual, pues se asemeja al ruego de una oración cristiana. La cercanía de la divinidad a los individuos de la colectividad náhuatl provoca que esta se integre, así, en la naturaleza y dependa más de ella.

$\mathrm{Al}$ igual que en el caso anterior, en el poema «Primavera y muchacha» podemos observar la supresión de la conjunción y entre los versos 15 y 16, y entre 17 y 18 , de manera que se configura una aparente ausencia que integre lo descrito por el locutor.

\author{
Basta un parpadeo $[y]$ \\ Todo reaparece en el mismo ojo
}




\author{
Brilla el mundo $[y]$
}

Tú resplandeces al filo del agua y de la luz

La desaparición de la conjunción copulativa provoca que realce la belleza como símbolo del reconocimiento del placer carnal. La primera supresión pretende impedir al lector tomar en cuenta la ilación entre ambas ideas, a fin de que no pueda identificar la recuperación del instante en que el hombre recupera las fuerzas después de la eyaculación, a la vez que fija su mirada en la mujer. En la segunda supresión, se procura también negar la ilación de la belleza que admira en el alocutario, por lo que el sujeto femenino emerge de entre ambos y estremece la mirada del hombre.

\title{
2.3.3. La antítesis en «Primavera y muchacha»
}

Los elementos o palabras que se muestran en un poema pueden ser contrarios si se pretende realzar la oposición de sus significados. En el caso del poema «Primavera y muchacha», el locutor contrapone los términos arriba y abajo entre los versos 3 y 6 para exponer los valores opuestos de la cultura china (yin yang).

\author{
Abajo \\ Un gran deseo de viaje remueve \\ Las entrañas heladas del lago \\ Cacerías de reflejos allá arriba
}

La posición de los opuestos arriba y abajo tiende a encontrar entre ambos la dualidad de lo superior y lo inferior para reconocer un conflicto que terminará por consumar el acto amoroso. La mujer se encuentra arriba en un inicio, lo que despierta el deseo en el hombre, cuya voluntad lo convencerá por ir de abajo hacia arriba y terminar ubicándose por encima de ella. Este juego de posiciones culminará en el intercambio de roles presente en los textos eróticos taoístas y que Octavio Paz recoge en su colección de ensayos Conjunciones y disyunciones. Por ello, la actitud del locutor de incidir en la oposición de lo femenino y lo masculino y su 
reinversión tiende a imitar «el ritmo dual —unión, separación, uniónde dos poderes o fuerzas: el cielo y la tierra, lo masculino y lo femenino, lo activo y lo pasivo» (Paz, 1991: 127). Este conflicto constante en la filosofía taoísta es necesario en el texto para dar a entender que se unen y complementan antes que verse en una lucha desigual.

\subsubsection{La reduplicación en «Fábula» y «Primavera y muchacha»}

El poema «Fábula» reúne una serie de elementos con los que el locutor aspira a mostrar cómo una sucesión de colores o sustantivos tiende a precisar la importancia de la divinidad natural para la sociedad náhuatl a partir de la figura del Sol como principio de vida de la colectividad.

\section{Del verde al amarillo}

\section{Del amarillo al rojo}

La reiteración del amarillo supone la necesidad de reafirmar los colores de Quetzalcóatl y su origen divino como serpiente emplumada o dios originario (el Sol). Tanto en las leyendas mayas como nahuas, el Quinto Sol es ocupado por Quetzalcóatl, de allí que el locutor tenga la necesidad de reafirmar dicho origen como reiteración y parte central de los colores que identifican a este dios mesoamericano. Quetzalcóatl es divino y humano al mismo tiempo; por ello, requiere de una identidad superior que reitere su poder en el poema: la repetición de su relación y conquista frente a otras divinidades.

En cuanto al poema «Primavera y muchacha», es posible observar la repetición de un elemento natural y brillante entre los versos 7 y 9, quizá no similar a una divinidad, pero sí central en la comprensión del texto.

La ribera ofrece guantes de musgo a tu blancura

La luz bebe luz en tu boca

Tu cuerpo se abre como una mirada

La reiteración del vocablo luz intenta representar la figura masculina en la filosofía taoísta erótica, pues identifica al hombre y al falo. Por lo 
https://doi.org/10.46744/bapl.202001.001

tanto, el locutor opta por describir el beso y el sexo oral como elementos centrales del universo amatorio en la cultura china. Así, el locutor no solo incorpora al alocutario como mujer y amante, sino que la posee en su lecho al penetrarla y sentir que vive en ella al identificar el acto mismo como vida (agua). El cuerpo es sometido a través de la luz porque puede entenderse como inicio de la fecundación y de la transmisión del placer como halo dominante. La reiteración, por lo tanto, cumple la función de enfatizar el dominio y la presencia determinante del falo como objeto de supremacía.

\section{El campo de las metáforas a partir de Lakoff y Johnson: Estudio comparativo de cuatro poemas de Semillas para un bimno}

En su clásico estudio sobre las Metáforas de la vida cotidiana, George Lakoff y Mark Johnson proponen un acercamiento al uso de las metáforas tanto en el lenguaje oral como en el discurso poético. Al respecto, proponen que este recurso obedece a un sistema lingüístico que requiere de significantes y significados emitidos por el emisor y que no son comprendidos por el receptor, dado que ocultan un mensaje que no es fácil de decodificar. Esta dificultad convierte a la metáfora en el recurso que los poetas utilizan para incorporar expresiones que necesitan de una interpretación que conozca las figuras o formas poéticas. En el caso de la poesía de Octavio Paz, recurrimos a algunos usos metafóricos y los explicamos a partir de algunas propuestas de Lakoff y Johnson como las metáforas orientacionales y las metáforas ontológicas.

En ese sentido, creemos pertinente indicar que empleamos estos recursos de interpretación para analizar los poemas «Fábula» $\mathrm{y}$ «Cerro de la estrella», y luego comparamos «Primavera y muchacha» $\mathrm{y}$ «[Una mujer de movimientos de río]». Los dos últimos textos presentan una relación cercana a las propuestas de la poesía oriental, por lo que se considera un estudio análogo. Aunque el primero es breve y podría contener una influencia del haiku, es necesario indicar que los códigos poéticos aztecas también tienen cierta injerencia. Para el caso de «Cerro de la estrella», no puede identificarse una influencia de la estética japonesa, pero sí algunos caracteres míticos que lo relacionan con «Fábula». 


\subsection{Las metáforas orientacionales}

\subsubsection{Las metáforas orientacionales en «Fábula» $\mathrm{y}$ «Cerro de la estrella»}

El poema presenta una extensión sumamente breve en relación con otros textos de Semillas para un bimno, por lo que su análisis nos permite encontrar las imágenes que quiere transmitir el locutor. El uso de términos como fuego, agua, luz y tiempo tienden a ocultar una serie de identificaciones con el universo náhuatl, tal como pudo verse en la sección anterior.

\section{Cerro de la estrella}

A Marco Antonio

y Ana Luisa Montes de Oca

Aquí los antiguos recibían al fuego

Aquí el fuego creaba al mundo

Al mediodía las piedras se abren como frutos

El agua abre los párpados

La luz resbala por la piel del día

Gota inmensa donde el tiempo se refleja y se sacia (2014, p. 191)

El locutor ofrece en el primer y segundo verso (Aquí los antiguos recibían el fuego / Aquí el fuego creaba el mundo) la dirección de observar el fuego como creador u originador de lo que poblamos y vemos en nuestro alrededor. Dicho elemento es elevado para contener la supremacía por sobre otros, ya que era divinizado como «calor, luz, protección». Se observa una base cultural que aproxima el fuego a los orígenes de los pueblos, dado que les proporciona seguridad y calor, a la vez que les permite identificarse con él. Miguel León-Portilla señala la importancia que tuvo el fuego para la sociedad náhuatl, ya que «sus dioses eran materiales; el fuego eterno era la materia eterna; los hombres eran hijos y habían sido creados por su padre el sol y por su madre la tierra» (1993: 35). La indicación de la piedra «al abrirse como frutos» evoca a la tierra, la madre de los hombres mesoamericanos que les otorga el alimento, la vida. 
https://doi.org/10.46744/bapl.202001.001

Puede hallarse, entonces, una relación sumamente estrecha con el poema «Fábula», dado que ambos hacen hincapié en la formación de las edades y los orígenes de los hombres. Así, el texto se inicia con el verso Edades de fuego y de aire, lo cual enfatizaría el fuego como origen del universo náhuatl, hecho que coincide en ambos poemas. Además, al introducir la metáfora orientacional, Paz incide en el fuego como directriz del cosmos mitológico. Así, en el verso 9 de «Fábula», observamos que «El calor reposaba al borde del estanque»; el locutor identifica al Sol (fuego) como elemento que, junto con el agua (estanque), posibilita el origen de las comunidades mesoamericanas. Esta dualidad divinizada tiene el dominio de dirigir los movimientos y la espiritualidad de los seres humanos, pues sin esta no sería posible que el hombre pueda comunicarse ni (re)crear todas las especies existentes. Asimismo, en el verso 11, se menciona la naturaleza como creación y dominación de parte del hombre-soberano (alocutario) al referir «en la palma de tu mano crecía un árbol», pues al estar en una posición semejante al soberano, se entiende que la vida de sus súbditos depende de él. Esta orientación supone que la colectividad está a merced del cacique, pues el locutor (creador de lo existente) le ha encomendado dicha tarea.

En «Cerro de la estrella», observamos una disposición metafórica similar al caso del poema anterior, dado que el locutor muestra una dirección que asocia los elementos de la divinidad con el colectivo mítico náhuatl. Así, entre los versos 4 y 6 leemos lo siguiente:

El agua abre los párpados

La luz resbala por la piel del día

Gota inmensa donde el tiempo se refleja y se sacia

La lluvia (agua) tiene la potestad de devolver la vida a la naturaleza y a los hombres, por lo que se produce una transformación por invocar la voluntad de los dioses para requerir de su sustento. La metáfora muestra una orientación hacia abajo, pues la lluvia se desplaza desde el cielo (morada divina) hacia los individuos (piel), en espera de un resultado positivo. 
ellos nos dan nuestro sustento, todo cuanto se bebe y se come, lo que conserva la vida, el maíz, el frijol, los bledos, la chía.

Ellos son a quienes pedimos agua, lluvia, por las que se producen las cosas en la tierra (León-Portilla, 1993: 131).

El texto que recoge León-Portilla en su estudio La filosofía nábuatl, muestra también la dirección «divinidad $\leftarrow$ lluvia $\rightarrow$ colectividad», factor que tiende a representar a la lluvia como intermediario entre ambos mundos (cielo-tierra / arriba-abajo). Esta orientación se relaciona con la salud, la vida y el control de los efectos sobrenaturales, por lo que es posible desprender una asociación de hechos construidos a partir de la esperanza y el vínculo con lo sagrado. El agua cumple el efecto mediador, dado que provee de alimento y salud a los individuos, y su presencia remarca una respuesta de agrado por parte de la divinidad, hecho que se corresponde con el tiempo (vida). En efecto, el agua otorgará más vida a la colectividad y el contacto con esta - a través de la lluvia — propiciará tiempos mejores para los hombres.

\subsubsection{Las metáforas orientacionales en «Primavera y muchacha» $\mathrm{y}$ en «[Una mujer de movimientos de río]»}

El poema «[Una mujer de movimientos de río]» no tiene título, por lo que hemos decidido utilizar el primer verso como tal. En él, Octavio Paz recurre a la imagen de la mujer como origen del orden mítico y como figura que se asocia con el agua como ente de origen. Se trata de un texto breve en el que el locutor intenta representar un cuadro con un personaje que distribuye los elementos de acuerdo con su presencia, y se mimetiza con el agua para construir su propio espacio en el texto. Veamos a continuación cómo se determinan los versos.

Una mujer de movimientos de río De transparentes ademanes de agua

Una muchacha de agua 
https://doi.org/10.46744/bapl.202001.001

Donde leer lo que pasa y no regresa

Un poco de agua donde los ojos beban

Donde los labios de un solo sorbo beban

El árbol la nube el relámpago

Yo mismo y la muchacha (2014: 190-191)

El poema proyecta la semejanza de la mujer con los movimientos del agua, los ríos, como si emergiera de ella un espíritu de pureza y de fuente de vida. El agua, además, regenera el ser y constituye un elemento cíclico, ya que discurre siempre en círculo. Al representar a la mujer como movimientos de río, el locutor enfatiza su sensualidad, sus movimientos, sus contornos. Paz entiende y decodifica esta sensualidad femenina tras su experiencia en Oriente, especialmente en India.

la actividad para alcanzar el Uno (masculino) no puede ser sino femenina (Sakti). Puesto que la actividad es de esencia masculina, la Sakti deberá expresar no solamente a la feminidad en su forma más plena — senos redondos, cintura estrecha, caderas poderosas - sino que esa feminidad pletórica ha de emitir efluvios, irradiaciones masculinas. (Paz, 1991: 112)

El locutor recrea la sensualidad femenina a partir de los vocablos ademanes de agua o los labios de un solo sorbo beban para definirla como efluvios o irradiaciones místicas del erotismo védico que la sociedad hindú posee. La posesión de la mujer y sus contornos como movimiento de un elemento erótico (pasión) puede entenderse como la admiración de la sensualidad que el locutor describe como «un poco de agua donde los ojos beban», es decir, el deleite de la vista ante el cuerpo femenino. Esta utilización del erotismo indio permite al locutor presentar la unidad del cuerpo femenino-masculino al enunciar el último verso. Además, el escenario se estremece y llega a un éxtasis amoroso al incorporar árboles, nubes, relámpago como elementos que cohesionan la pasión de los amantes.

Las metáforas orientacionales en el poema «[Una mujer de movimientos de río]» no son muy comunes y apenas podemos notar 
una en el recorrido del agua a través del cuerpo de la mujer, lo cual puede significar el espíritu divino del sujeto femenino, pues este toma la forma de un río.

\section{Una mujer de movimientos de río}

De transparentes ademanes de agua

La mujer puede adoptar la forma y los movimientos de un río, lo que se traduce en la forma en que se presenta ante el amado. El sujeto femenino se dirige de un lado a otro, representa una orientación que emerge como las aguas hacia el cauce (arriba-abajo), pero también la sensualidad. Al ser transparente, se hace referencia a la pureza (virginidad) de la mujer como punto de llegada hacia donde debe dirigirse el hombre (orientación). La sensualidad es el clímax del poema y refiere a los ademanes con que transita el agua, por lo que virginidad y sensualidad refieren a una adolescente que usa su figura para atraer la mirada masculina. Esta última característica tiende a aclararse en el verso 5, cuando el locutor enuncia «Un poco de agua donde los ojos beban»: es decir, los ojos han bebido (poseído) el cuerpo de la mujer a la vez que han direccionado la mirada hacia arriba, a manera de un orden superior que empodera la sensualidad femenina.

En el caso de «Primavera y muchacha», observamos quizá una orientación más clara en cuanto a la disposición de los amantes, ya que se muestra una ubicación de ascendencia en el papel de quienes asumen el rol erótico. De esta manera, el hombre, ubicado en la parte inferior, decide ir al encuentro de la mujer, la cual toma la posición superior.

\footnotetext{
Abajo

Un gran deseo de viaje remueve

Las entrañas heladas del lago

Cacerías de reflejos allá arriba
}

La dirección arriba-abajo orienta la metáfora hacia una situación de dominación femenina, pues el deseo de viaje (ascenso) supone el deseo de poseer a la amada a partir de un factor de elevación del sujeto femenino, 
cuyas entrañas heladas deben ser tomadas por el varón. El campo visual que se muestra favorece la ubicación de quien está subiendo porque la mujer parece quieta ante el gran deseo de su par masculino. Este viaje direccional tiene como fin la consumación del acto erótico y conducir al hombre al combate o cacería (coito). Sin embargo, en el verso 14, leemos que «todo se precipita en un ojo sin fondo», es decir, una caída hacia el interior de la vagina (ojo). Dicha oposición de direcciones tiende a orientar la exaltación del clímax amoroso con el encuentro de los amantes y concluye con el descenso del placer erótico con la eyaculación.

\subsection{Las metáforas ontológicas}

\subsubsection{Las metáforas ontológicas en «Fábula» $\mathrm{y}$ «Cerro de la estrella»}

Lakoff y Johnson sostienen que las metáforas ontológicas son las de uso más común en el habla popular, ya que constantemente son empleadas por las personas en su vida diaria. Se utiliza la personificación para especificar la equivalencia de una persona con un objeto, es decir, humanizar las cosas o viceversa. Existe también la metonimia como figura que se relaciona a partir de la parte por el todo, el objeto por el usuario, la institución por el personal, etc.

El poema «Fábula» presenta algunas metáforas ontológicas en las que prevalece la personificación de algunos elementos que dominan el espacio poético propuesto por el locutor. Así, observamos la descripción de la lluvia como un sauce de pelo suelto en el verso 10. Esta definición a la que apela el poeta es central en la estructura metafórica del texto, ya que, como el sauce es un árbol identificado con la riqueza en el universo náhuatl, era necesario que este tuviera relación con la lluvia (agua). La utilización de este recurso poético aclara el sentido humano del objeto, por cuanto incide en la característica del pelo suelto y lo humaniza al otorgarle una forma humedecida en las hojas, que lo compara con las gotas de lluvia sobre el cabello. Esta imagen es trascendental, pues, en los versos siguientes, identifica al curaca como nacido de un árbol, lo que enfatizaría su rol mediador entre la naturaleza (divinidad) y los hombres. Se trata de un sacerdote náhuatl que se aproxima a su colectividad en forma arborícola. 
De allí que indique que «aquel árbol cantaba reía profetizaba» y de sus ramas nacen los pájaros y la vida misma en la colectividad azteca.

En los últimos versos, el locutor hace hincapié en el uso de la palabra como milagro de la existencia divina de los hombres, pues remite su origen al sol como fuente de vida (luz).

Palabra como un sol

Un día se rompió en fragmentos diminutos

Son las palabras del lenguaje que hablamos

La metáfora ontológica de la fragmentación de la palabra es esencial para comprender por qué la ruptura de la comunicación es una tragedia, ya que esta impide la conexión con la divinidad y se producen los cataclismos y la inversión del orden mítico. En consecuencia, los humanos dejan de ser divinos para emplear un lenguaje que los expulsa del espacio sagrado. La fragmentación del idioma separa a los hombres y los disgrega de ese origen común, que es el árbol.

En el poema «Cerro de la estrella», se apela a una metáfora ontológica que es central para la decodificación del texto, pues se asume la importancia que debe cumplir el fuego como ordenador del universo mítico. Así, en los versos 5 y 6 , el locutor reafirma el papel de la luz como eje del poema.

La luz resbala por la piel del día

Gota inmensa donde el tiempo se refleja y se sacia

La presencia del fuego como ente ordenador del espacio poético es necesaria para comprender la temática del texto. El sol (fuego, luz) irradia vida sobre los individuos, los ilumina y les otorga mayor capacidad (tiempo) para enfrentar la muerte o las enfermedades. Los ritos que se dirigen en esta parte del texto contribuyen a incrementar el sentido del poema, pues suponen mayor voluntad para excavar en la memoria de los habitantes mexicas. Ambos poemas, «Fábula»y «Cerro de la estrella», inciden en las imágenes de los orígenes y de la destrucción del orden mítico como cataclismos que conducirán a la incomprensión de la especie humana, así 
como la aparición de los desvalores que podrían conducir al desequilibrio entre hombre y naturaleza.

\subsubsection{Metáforas ontológicas en «Primavera y muchacha» $\mathrm{y}$ « [Una mujer con movimientos de río]»}

Es particularmente interesante entender el uso de la metáfora ontológica en el poema «Primavera y muchacha» porque remite a elementos culturales propios del universo erótico taoísta, factor que contribuyó a ampliar sobremanera el universo poético de Octavio Paz. Como pudo explicarse en el acápite anterior, la referencia a elementos amorosos y eróticos es quizá el factor central de este poema. Así, en los versos 9 y 10, el locutor enfatiza en el valor comparativo del órgano genital para ordenar el sentido del texto en función de la conquista sexual de la mujer por parte del hombre.

Tu cuerpo se abre como una mirada

Como una flor al sol de una mirada

La disposición de la mujer para sentirse sometida por el hombre es un aspecto central, porque destaca no solo la metonimia (cuerpo por vagina), sino que dirige la atención del lector a buscar la figura del hombre (sol) que penetra con sus rayos a la mujer (flor). Esta construcción de valores estéticos que remiten a objetos naturales ayuda a entender la finalidad del texto: describir la consumación del acto sexual. La mirada masculina (deseo de posesión) se ve finalmente dirigida al objeto de deseo como una contemplación amatoria que conducirá al acto.

En los versos 18 y 19, se describe también la finalización del acto erótico a través de la admiración de la mujer poseída y la felicidad de los amantes. Como se precisó en el segundo segmento del artículo, la filosofía taoísta reconoce en la unión del hombre y la mujer la complementación de contrarios o yin yang (agua-luz), pues el texto describe a los dos cuerpos que se han unido.

Tú resplandeces al filo del agua y de la luz

Eres la hermosa máscara del día 
La metáfora ontológica propone el valor del cuerpo femenino como un rostro nuevo que despierta con el alba, pues ha permitido que la experiencia coital consuma el placer en la capacidad de mutación (la mujer ha transformado su presencia en divinidad). En efecto, la máscara tiende a desaparecer el cuerpo de la amante por un no-cuerpo (Paz, 1991: 146) y lo señala como espacio final de un estado de cercanía con la supremacía del ser. La consecución del fenómeno amatorio conduce a los amantes a verse expuestos al placer carnal, a diferencia del universo occidental, que prohíbe todo acto erótico por considerarlo pecaminoso y no civilizado (p. 146).

Finalmente, en «[Una mujer con movimientos de río]», se emplea una metáfora que reproduce la unión de los amantes al describir la sensualidad de la mujer como eje de provocación hacia el hombre. De esta forma, en los versos 6 al 8 , puede observarse la presencia de elementos naturales que simbolizarían el encuentro de los amantes.

Donde los labios de un solo sorbo beban

El árbol la nube el relámpago

Yo mismo y la muchacha

El empleo de vocablos como nube o relámpago en la filosofía taoísta remite a la presencia femenina y masculina, respectivamente, las cuales tienen el árbol o campo natural como escenario de su amor. Este encuentro del locutor con la mujer (alocutario no representado) cumple funciones similares a las de «Primavera y muchacha», pero no tan directas como este. Podría decirse, en consecuencia, que el uso del acto amatorio es más sutil en este poema, ya que apela solo a los contornos y los movimientos corporales del sujeto femenino antes que a la descripción del acto erótico. El análisis de este recurso nos ha permitido, por ello, descifrar el valor estético que estos poemas contienen en cuanto a la poetización de otras civilizaciones.

\section{Conclusiones}

Los autores que se han encargado de estudiar la obra de Octavio Paz rescatan el aporte prehispánico de Semillas para un bimno, pero no toman 


$$
\text { https://doi.org/10.46744/bapl.202001.001 }
$$

en cuenta la presencia de las sociedades orientales. Por ello, se intenta aproximar hacia nuevos estudios que permitan un mejor análisis de los textos seleccionados.

El origen mítico y el acto erótico legitiman la libertad del autor para adentrarse en mundos aparentemente diferentes y encontrar en ellas una esencia común: el fuego y la luz representan el valor central en la propuesta poética de Semillas para un himno.

El campo figurativo propuesto en estos poemas permite descubrir figuras que contienen valores estéticos relacionados con el dominio de los ancestros masculinos (sol, fuego) y la posesión o dominación del sujeto femenino (agua, lluvia) para una adecuada participación de la colectividad.

Las metáforas orientacionales posibilitan hallar la directriz con que las figuras míticas son representadas en los poemas analizados a partir de una transformación de los roles adoptados por los personajes. Las metáforas ontológicas muestran la esencia de cada texto y su decodificación a partir de formas nahuas o asiáticas. De esta forma, Paz encuentra el origen común poético entre ambos mundos. 
https://doi.org/10.46744/bapl.202001.001

\section{BIBLIOGRAFÍA}

ARDUINI, S. (2000). Prolegómenos a una teoría general de las figuras. Murcia: Universidad de Murcia.

FERNÁNDEZ, C. (1996). Las huellas del aura. La poética de J. E. Eielson. Lima-Berkeley: Latinoamericana Editores.

. (2015). El referente prehispánico y la poliacroasis en $L a$ estación violenta (1948-1957) de Octavio Paz. Tonos Digital (29). Consulta: 26 de julio de 2015. Recuperado de http:// www.tonosdigital.es/ojs/index.php/tonos/article/view/1311

LAKOFF, G. \& JOHNSON, M. (1995). Metáforas de la vida cotidiana. Madrid: Cátedra.

LEÓN-PORTILLA, M. (Ed.) (1978). Literatura del México antiguo. Los textos en lengua nábuatl. México: Biblioteca Ayacucho.

. (1993). La filosofía nábuatl. Estudiada en sus fuentes. México: Universidad Nacional Autónoma de México.

PAZ, O. (1967). Corriente alterna. México: Siglo XXI Editores.

. (1974). Los bijos del limo. Del romanticismo al vanguardismo. Barcelona: Seix Barral.

. (1991). Conjunciones y disyunciones. Barcelona: Seix Barral.

. (1998). El laberinto de la soledad. E. Santí, ed. Madrid: Cátedra.

. (2014). Libertad bajo palabra (1935-1957). E. Santí, ed. Madrid: Cátedra.

PURO, A. (1982). El amor en la poesía de Octavio Paz. Aproximación a Semillas para un bimno. Cauce, 5, 143-155. 
STANTON, A. (1992). Huellas precolombinas en Semillas para un himno de Octavio Paz. En Actas del XI Congreso de Asociación Internacional de Hispanitas, IV, 11-20.

SUCRE, G. (1971). La fijeza y el vértigo. Revista Iberoamericana, 74(37), 47-72.

YURKIEVICH, S. (1971). Fundadores de la nueva poesía latinoamericana. Vallejo, Huidobro, Borges, Neruda, Paz. Barcelona: Barral Editores.

. (1971). Octavio Paz, indagador de la palabra. Revista Iberoamericana, 74(37), 73-95.

WOLF, N. (2013). Vagina. Una nueva biografía de la sexualidad femenina. Barcelona: Kairós. 